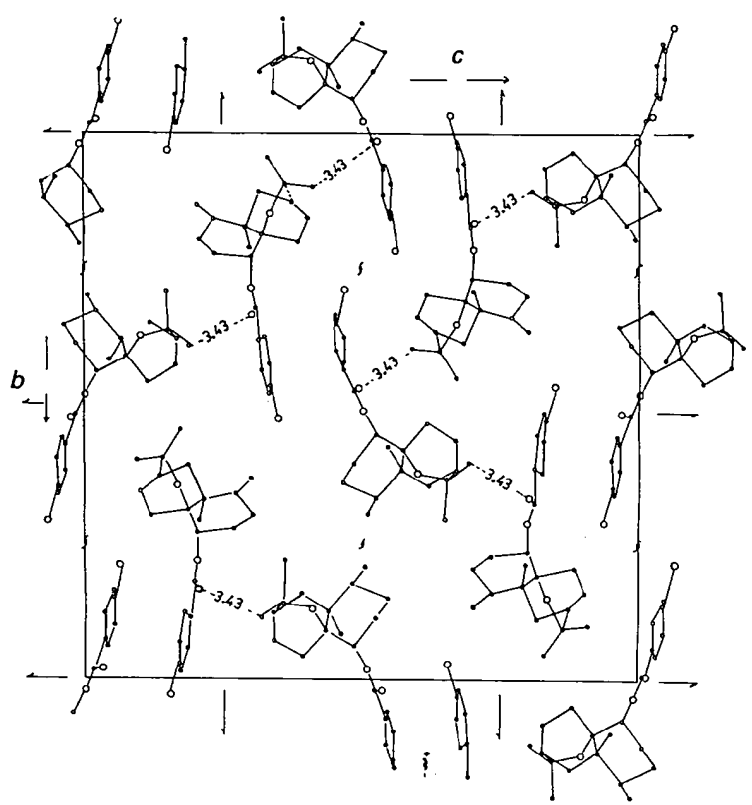

Fig. 3. Packing diagram of the molecules down the $a$ axis with intermolecular short contacts $(\AA)$.

(without a bridge) is in the chair form. In the cyclohexane ring having the chair conformation, the distance between the planes containing alternate atoms is about $0.433 \AA$. In the cyclohexane ring having the boat conformation, the atoms forming the 'bottom' of the boat are not exactly coplanar. The deviations of $\mathrm{C} 18$ from the planes passing through $\mathrm{C16}, \mathrm{C15}$, C19 in molecule $A$ and in molecule $B$ are 0.296 (6) and $0.286(5) \AA$, respectively.

Acta Cryst. (1991). C47, 1426-1429
In molecule $A, \mathrm{Br} 1$ and $\mathrm{O} 9$ are on the opposite sides of the benzene plane, the distances of $\mathrm{Brl}, \mathrm{O}$, O10 from this plane being $-0 \cdot 106(1), 0 \cdot 124(7)$ and -0.354 (7) $\AA$, respectively. In molecule $B$, however, $\mathrm{Br} 1$ and $\mathrm{O} 9$ are on the same side of the benzene plane, the distances of $\mathrm{Brl}, \mathrm{O} 9, \mathrm{O} 10$ from this plane being $-0.035(2), \quad-0.053(8)$ and $0.173(7) \AA$, respectively. The dihedral angle between the benzene plane and the plane of the $(\mathrm{C} 8, \mathrm{O} 9, \mathrm{O} 10)$ group is $12.8(10)^{\circ}$ in molecule $A$ and $5.9(10)^{\circ}$ in molecule $B$. Many intramolecular short contacts are present but the intermolecular forces are apparantly small [shortest contact $\mathrm{C} \cdots \mathrm{O}, 3.43(2) \AA$ ]. This implies that the molecules are somewhat loosely bound to each other. It is therefore not surprising that the melting point of the compound is rather low (observed m.p. $395 \mathrm{~K})$.

\section{References}

Jenner, P. M., Hagan, E. C., TAylor, J. M., COOK, E. L. \& Firzhugh, O. G. (1964), Food Cosmet. Toxicol. 2, 327-329.

Main, P., Hull, S. E., Lessinger, L., Germain, G., DeclercQ, J.-P. \& Woolfson, M. M. (1978). MULTAN78. A System of Computer Programs for the Automatic Solution of Crystal Structures from X-ray Diffraction Data. Univs. of York, England, and Louvain, Belgium.

Maruzzella, C. J. \& Balker, J. (1959). Plant Dis. Rep. 43, 1143-1145.

Maruzzella, C. J. \& Bramnick, E. (1961). Soap Perfum. Cosmet. 34, 743-744.

Ray, S. (1986). Studies on Natural Products. PhD Thesis, pp. 192-194. Jadavpur Univ., India.

Rohmer, M., Schwartz, A. C. \& Anton, R. (1977). Phytochemistry, 16, 773-774.

Sheldrick, G. M. (1976). SHELX76. Program for crystal structure determination. Univ. of Cambridge, England.

\title{
Structure of 17-Epinimbocinol
}

\author{
By Kalyan Das and U. C. Sinha* \\ Department of Physics, Indian Institute of Technology, Bombay-400 076, India \\ T. Mayelvaganan and S. V. Bhat \\ Department of Chemistry, Indian Institute of Technology, Bombay-400 076, India
}

AND S. S. TAVALE

Physical and Structural Chemistry Unit, National Chemical Laboratory, Pune-411 008, India

(Received 17 July 1990; accepted 15 October 1990)

Abstract. $\quad 7 \alpha$-Hydroxy-4,4,8-trimethyl-21,23-epoxy24 -nor-5 $\alpha, 13 \alpha, 17 \beta$-chola-1,14,20,22-tetraene-3,16-

* To whom correspondence should be addressed.

0108-2701/91/071426-04\$03.00 dione, $\mathrm{C}_{26} \mathrm{H}_{32} \mathrm{O}_{4}, M_{r}=408 \cdot 51$, m.p. $=526-528 \mathrm{~K}$, orthorhombic, $\quad P 2_{1} 2_{1} 2_{1}, \quad a=6.7094(9), \quad b=$ $13 \cdot 195(1), c=24 \cdot 281$ (3) $\AA, V=2149 \cdot 64 \AA^{3}, Z=4$, $D_{x}=1.262 \mathrm{Mg} \mathrm{m}^{-3}, \quad \lambda(\mathrm{Cu} \mathrm{K \alpha})=1.5418 \AA, \quad \mu=$

(C) 1991 International Union of Crystallography 
$0.584 \mathrm{~mm}^{-1}, \quad F(000)=880, T=291 \mathrm{~K}$, final $R=$ $0.0361, w R=0.0449$ for 1820 observed reflections. The $A-B$ and $B-C$ rings are trans fused. The $\mathrm{C}(17)$ furan ring is trans to the $\mathrm{C}(13)$ methyl and is in the $\beta$-position. Intermolecular $\mathrm{O}-\mathrm{H} \cdots \mathrm{O}$ and $\mathrm{C}-\mathrm{H} \cdots \mathrm{O}$ interactions are present.

Introduction. Azadirachta indica Juss (syn. Melia azadirachta; L. Melia indica Margosa), commonly known as neem or nimba, belongs to the family Meliaceae and is widely distributed in tropical parts of the world. This plant is well known for its pesticidal activity (Schmutterer, Ascher \& Rembold, 1980; Schmutterer \& Ascher, 1983) and various other important medicinal properties (Siddiqui, Siddiqui, Faizi \& Mahmood, 1988). The nimbidin fraction of the neem oil was found to exhibit antiarthritic, antiinflammatory (Pillai \& Santhakumari, 1981) and antiulcer properties (Pillai \& Santhakumari, 1984). The crystal structure of the title compound was studied by X-ray diffraction methods in order to determine the relative stereochemistry.

Experimental. The title tetranortriterpene alcohol (1) was isolated from the nimbidin fraction of the methanol extract of industrial grade neem oil by hydrolysis in a Parr pressure reactor, followed by removing the fatty acids by vacuum distillation and purifying over silica gel with benzene-ethyl acetate (Gaikwad, Mayelvaganan, Vyas \& Bhat, 1990). The compound was crystallized from methanol, under ambient conditions, as colourless needles.

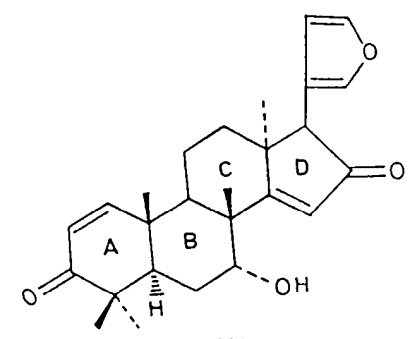

(1)

A crystal of dimensions $0.4 \times 0.5 \times 0.4 \mathrm{~mm}$ was selected for intensity data collection on an EnrafNonius CAD-4 diffractometer with $\mathrm{Cu} K \alpha$ radiation. Unit-cell parameters were refined from 25 reflections in the range $19 \leq \theta \leq 38^{\circ}$. Three standard reflections $(\overline{1} 4 \overline{7}, \overline{3} 5 \overline{8}, \overline{2} 3 \overline{5})$, measured every $3600 \mathrm{~s}$, showed no significant intensity variation. Using the $\omega-2 \theta$ scan technique, a total of 1881 unique reflections were measured in the range $2 \leq \theta \leq 60^{\circ}, h_{\max }=7, k_{\max }=$ 14 and $l_{\max }=27$. Data were corrected for Lp factors and absorption was neglected. The structure was solved by direct methods using MULTAN84 (Main, Germain \& Woolfson, 1984). Non-H atoms were refined with anisotropic thermal parameters. All $\mathrm{H}$ atoms were located from a difference map and refined isotropically. The structure refinement was by full-matrix least squares based on $F$ values. In the final refinement, 399 parameters were refined using 1820 observed reflections with $\left|F_{o}\right| \geq 3 \sigma\left|F_{o}\right|$. Final $R=0.0361$ and $w R=0.0449$ where $w=1.000 /[\sigma(F)$ $\left.\left.+0.00157 F^{2}\right]\right\}$. In the final difference map, $(\Delta \rho)_{\max }=$ 0.156 and $(\Delta \rho)_{\min }=-0.138 \mathrm{e} \AA^{-3},(\Delta / \sigma)_{\max }=0.062$. SHELX76 (Sheldrick, 1976) was used for the structure refinement and a CYBER 180/840 for computations. Atomic scattering factors were those of SHELX76.

Discussion. The atomic coordinates are listed in Table 1, and bond lengths and bond angles are in Table 2.* Fig. 1 is a PLUTO (Motherwell \& Clegg, 1978) diagram of the molecule. The cyclohexane rings $A-B$ and $B-C$ are fused in the trans fashion, with torsion angles about $\mathrm{H}(5)-\mathrm{C}(5)-\mathrm{C}(10)-\mathrm{C}(22)$ and $\mathrm{H}(9)-\mathrm{C}(9)-\mathrm{C}(8)-\mathrm{C}(23)$ of 178.7 (4) and $177.6(4)^{\circ}$ respectively. Ring $B$ has a chair conformation; $C(5)$ and $C(8)$ are $0.743(2)$ and $-0.620(2) \AA$ respectively out of the mean plane formed by the other four ring atoms [maximum deviation $\pm 0.003(2) \AA]$. Ring $C$ exists almost in a half-chair conformation with $\mathrm{C}(9)$ and $\mathrm{C}(13)$ deviating from the least-squares plane passing through the remaining four atoms by 0.710 (2) and -0.541 (4) $\AA$. The other six-membered ring, $A$, is a twisted boat shape $[C(4)$ and $C(10)$ are $-0.384(3)$ and $-0.465(3) \AA$ respectively out of the mean plane passing through $C(1), C(2), C(3)$ and $C(5)$ within a maximum deviation of 0.099 (3) $\AA$ ]. In the case of 7-acetylneotrichilenone (Kraus, Cramer \& Sawitzki, 1981), extracted from same plant, all these three rings are in a chair conformation. The fivemembered ring has an envelope shape with $C(16)$ $-0.215(2) \AA$ out of the plane passing through the remaining four atoms [maximum deviation of $\pm 0.09(2) \AA]$. The furan ring attached to $C(17)$ is planar and trans to the $\mathrm{C}(13)$ methyl atom $[\mathrm{C}(18)$ $\mathrm{C}(17)-\mathrm{C}(13)-\mathrm{C}(24), 141 \cdot 3^{\circ}$; in 7-acetylneotrichilenone it is cis (Kraus, Cramer \& Sawitzki, 1981). The furan ring is in the $\beta$-position. The methyl $C(22)$ and $\mathrm{C}(23)$ atoms are $\beta$, whereas $\mathrm{C}(24)$ and $\mathrm{O}(2)$ are in an $\alpha$-orientation (Table 2). The $\mathrm{C}-\mathrm{C}$ bond distances to the methyl $\mathrm{C}$ atom are close to normal values [mean $1.541(4) \AA]$. However, in cyclopentane rings the $\mathrm{C}\left(s p^{3}\right)-\mathrm{C}\left(s p^{3}\right)$ bond distances range from $1.434(4)$ to 1.569 (3) $\AA$ with an average value of 1.527 (4) $\AA$, indicative of strain in the molecule. The bond dis-

\footnotetext{
* Lists of structure factors, anisotropic thermal parameters, least-squares planes and $\mathrm{H}$-atom parameters have been deposited with the British Library Document Supply Centre as Supplementary Publication No. SUP 53655 (14 pp.). Copies may be obtained through The Technical Editor, International Union of Crystallography, 5 Abbey Square, Chester $\mathrm{CH} 12 \mathrm{HU}$, England.
} 
Table 1. Final positional parameters $\left(\times 10^{4}\right)$ and equivalent temperature factors $\left(\AA^{2} \times 10^{3}\right)$ with e.s.d.'s in parentheses

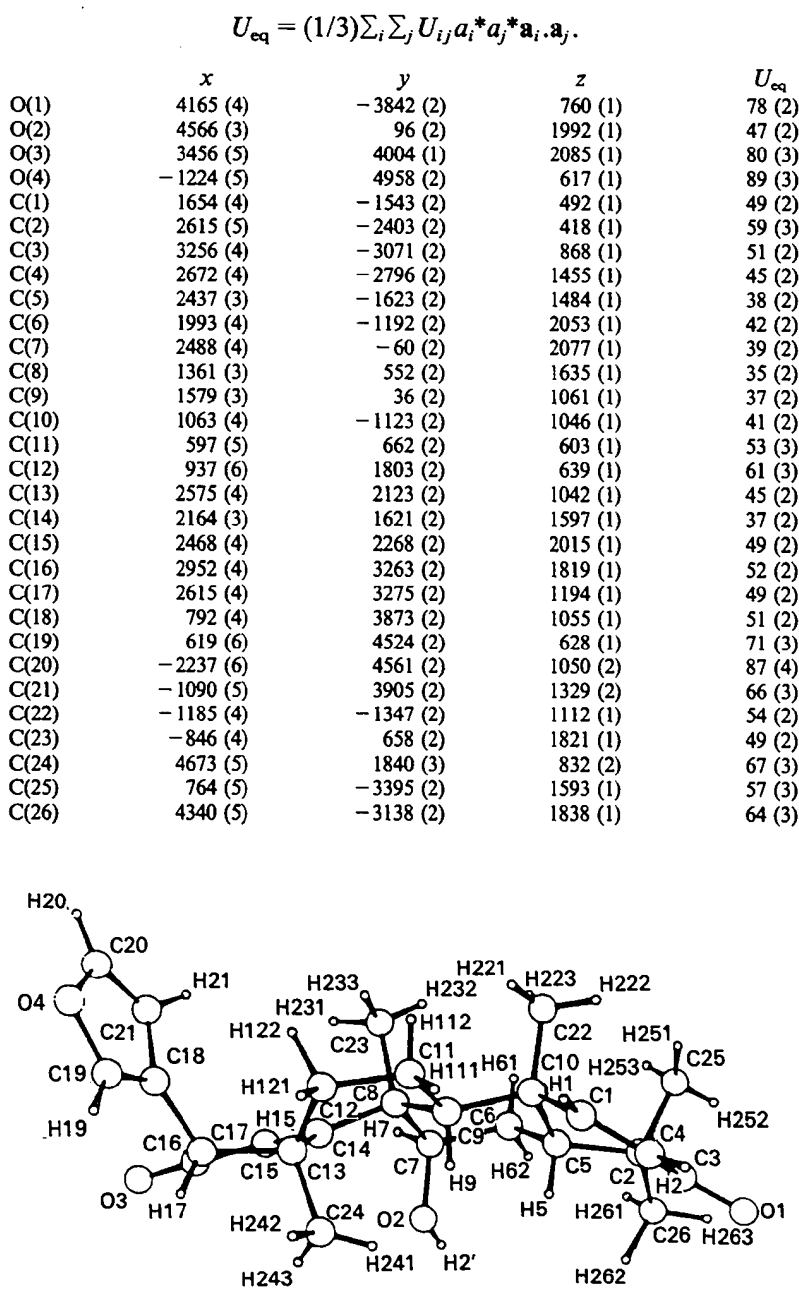

Fig. 1. Perspective view of the molecule.

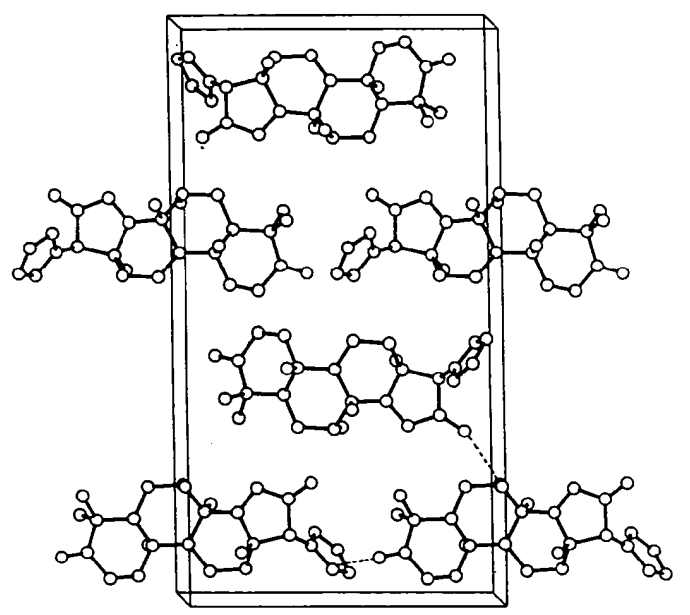

Fig. 2. Unit-cell packing diagram.
Table 2. Bond lengths $(\AA)$, bond angles $\left({ }^{\circ}\right)$, torsion angles $\left(^{\circ}\right)$ and hydrogen-bond geometry $\left(\AA,{ }^{\circ}\right)$ with e.s.d.'s in parentheses

$\begin{array}{llll}C(3)-O(1) & 1.215(3) & C(14)-C(8) & 1.512(3) \\ C(7)-O(2) & 1.425(3) & C(23)-C(8) & 1.555(3) \\ C(16)-O(3) & 1.218(3) & C(10)-C(9) & 1.569(3) \\ C(19)-O(4) & 1.363(5) & C(11)-C(9) & 1.533(3) \\ C(20)-O(4) & 1.358(6) & C(22)-C(10) & 1.545(3) \\ C(2)-C(1) & 1.317(4) & C(12)-C(11) & 1.525(4) \\ C(10)-C(1) & 1.507(3) & C(13)-C(12) & 1.532(4) \\ C(3)-C(2) & 1.468(4) & C(14)-C(13) & 1.527(3) \\ C(4)-C(3) & 1.522(3) & C(17)-C(13) & 1.564(3) \\ C(5)-C(4) & 1.558(3) & C(24)-C(13) & 1.543(4) \\ C(25)-C(4) & 1.542(4) & C(15)-C(14) & 1.342(3) \\ C(26)-C(4) & 1.524(4) & C(16)-C(15) & 1.434(4) \\ C(6)-C(5) & 1.522(3) & C(17)-C(16) & 1.536(3) \\ C(10)-C(5) & 1.555(3) & C(18)-C(17) & 1.494(4) \\ C(7)-C(6) & 1.531(3) & C(19)-C(18) & 1.350(4) \\ C(8)-C(7) & 1.542(3) & C(21)-C(18) & 1.428(5) \\ C(9)-C(8) & 1.558(3) & C(21)-C(20) & 1.341(5)\end{array}$

$\mathrm{C}(20)-\mathrm{O}(4)-\mathrm{C}(19) \quad 106.0(2) \quad \mathrm{C}(9)-\mathrm{C}(10)-\mathrm{C}(1) \quad 108 \cdot 7(2)$ $\mathrm{C}(10)-\mathrm{C}(1)-\mathrm{C}(2) \quad 124.6(2) \quad \mathrm{C}(9)-\mathrm{C}(10)-\mathrm{C}(5)$

$\begin{array}{llll}\mathrm{C}(3)-\mathrm{C}(2)-\mathrm{C}(1) & 124.0(2) & \mathrm{C}(22)-\mathrm{C}(10)-\mathrm{C}(1) & 106.2(2)\end{array}$

$\mathrm{C}(2)-\mathrm{C}(3)-\mathrm{O}(1) \quad 119.4(2) \quad \mathrm{C}(22)-\mathrm{C}(10)-\mathrm{C}(5) \quad 115.2(2)$

$\mathrm{C}(4)-\mathrm{C}(3)-\mathrm{O}(1) \quad 122.0(2) \quad \mathrm{C}(22)-\mathrm{C}(10)-\mathrm{C}(9) \quad 113.5(2)$

$\mathrm{C}(4)-\mathrm{C}(3)-\mathrm{C}(2) \quad 118.6(2) \quad \mathrm{C}(12)-\mathrm{C}(11)-\mathrm{C}(9) \quad 115.3(2)$

$\mathrm{C}(5)-\mathrm{C}(4)-\mathrm{C}(3) \quad 107.8(2) \quad \mathrm{C}(13)-\mathrm{C}(12)-\mathrm{C}(11) \quad 114.6(2)$

$\mathrm{C}(25)-\mathrm{C}(4)-\mathrm{C}(3) \quad 107.2(2) \quad \mathrm{C}(14)-\mathrm{C}(13)-\mathrm{C}(12) \quad 108.4(2)$

$\mathrm{C}(25)-\mathrm{C}(4)-\mathrm{C}(5) \quad 114.5(2) \quad \mathrm{C}(17)-\mathrm{C}(13)-\mathrm{C}(12) \quad 115.5(2)$

$\mathrm{C}(26)-\mathrm{C}(4)-\mathrm{C}(3) \quad 108.2(2) \quad \mathrm{C}(17)-\mathrm{C}(13)-\mathrm{C}(14) \quad 102.6(2)$

$\begin{array}{llll}\mathrm{C}(26)-\mathrm{C}(4)-\mathrm{C}(5) & 109.9(2) & \mathrm{C}(24)-\mathrm{C}(13)-\mathrm{C}(12) & 112.1(3)\end{array}$

$\mathrm{C}(26)-\mathrm{C}(4)-\mathrm{C}(25) \quad 109.0(2) \quad \mathrm{C}(24)-\mathrm{C}(13)-\mathrm{C}(14) \quad 110.6(2)$

$\mathrm{C}(6)-\mathrm{C}(5)-\mathrm{C}(4) \quad 115.6(2) \quad \mathrm{C}(24)-\mathrm{C}(13)-\mathrm{C}(17) \quad 107.3(2)$

$\begin{array}{llll}C(10)-C(5)-C(4) & 116.8(2) & C(13)-C(14)-C(8) & 121.5(2)\end{array}$

$\begin{array}{llll}\mathrm{C}(10)-\mathrm{C}(5)-\mathrm{C}(6) & 110.3(2) & \mathrm{C}(15)-\mathrm{C}(14)-\mathrm{C}(8) & 127.0(2)\end{array}$

$\begin{array}{llll}C(7)-C(6)-C(5) & 110.9(2) & C(15)-C(14)-C(13) & 111.3(2)\end{array}$

$\begin{array}{llll}\mathrm{C}(6)-\mathrm{C}(7)-\mathrm{O}(2) & 110.3(2) & \mathrm{C}(16)-\mathrm{C}(15)-\mathrm{C}(14) & 111.5(2)\end{array}$

$\begin{array}{llll}C(8)-C(7)-O(2) & 107.7(2) & C(15)-C(16)-O(3) & 128.4(3)\end{array}$

$\mathrm{C}(8)-\mathrm{C}(7)-\mathrm{C}(6) \quad 112.3(2) \quad \mathrm{C}(17)-\mathrm{C}(16)-\mathrm{O}(3) \quad 123.8(3)$

$\mathrm{C}(9)-\mathrm{C}(8)-\mathrm{C}(7) \quad 110.3(2) \quad \mathrm{C}(17)-\mathrm{C}(16)-\mathrm{C}(15) \quad 107.7(2)$

$\begin{array}{llll}C(14)-C(8)-C(7) & 110.9(2) & C(16)-C(17)-C(13) & 103.0(2) \\ C(14)-C(8)-C(9) & 108.7(2) & C(18)-C(17)-C(13) & 116.5(2)\end{array}$

$\begin{array}{llll}C(14)-C(8)-C(9) & 108.7(2) & C(18)-C(17)-C(13) & 116.5(2)\end{array}$

$\begin{array}{llll}\mathrm{C}(23)-\mathrm{C}(8)-\mathrm{C}(7) & 108.1(2) & \mathrm{C}(18)-\mathrm{C}(17)-\mathrm{C}(16) & 110.4(2)\end{array}$

$\mathrm{C}(23)-\mathrm{C}(8)-\mathrm{C}(9) \quad 112.9(2) \quad \mathrm{C}(19)-\mathrm{C}(18)-\mathrm{C}(17) \quad 125.4(3)$

$\mathrm{C}(23)-\mathrm{C}(8)-\mathrm{C}(14) \quad 105.9(2) \quad \mathrm{C}(21)-\mathrm{C}(18)-\mathrm{C}(17) \quad 129.4(2)$

$\begin{array}{llll}\mathrm{C}(10)-\mathrm{C}(9)-\mathrm{C}(8) & 115.2(2) & \mathrm{C}(21)-\mathrm{C}(18)-\mathrm{C}(19) & 105.2(3)\end{array}$

$\begin{array}{llll}\mathrm{C}(11)-\mathrm{C}(9)-\mathrm{C}(8) & 111.9(2) & \mathrm{C}(18)-\mathrm{C}(19)-\mathrm{O}(4) & 111.2(3)\end{array}$

$\mathrm{C}(11)-\mathrm{C}(9)-\mathrm{C}(10) \quad 114.5(2) \quad \mathrm{C}(21)-\mathrm{C}(20)-\mathrm{O}(4) \quad 110.6(4)$

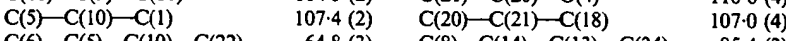

$\mathrm{C}(6)-\mathrm{C}(5)-\mathrm{C}(10)-\mathrm{C}(22) \quad-64.8(3) \quad \mathrm{C}(8)-\mathrm{C}(14)-\mathrm{C}(13)-\mathrm{C}(24) \quad 85.4$ (3)

$\mathrm{C}(5)-\mathrm{C}(6)-\mathrm{C}(7)-\mathrm{O}(2) \quad-63.4(3) \quad \mathrm{C}(14)-\mathrm{C}(13)-\mathrm{C}(17)-\mathrm{C}(18) \quad 77.8(2)$

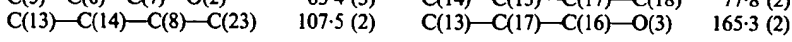

\begin{tabular}{lclcl} 
& $\mathrm{C} \cdots \mathrm{O} / \mathrm{O} \cdots \mathrm{O}$ & $\mathrm{H} \cdots \mathrm{O}$ & $\mathrm{C}-\mathrm{O}-\mathrm{H} \cdots \mathrm{O} /$ & \multicolumn{1}{c}{ Symmetry } \\
$\mathrm{O}(2)-\mathrm{H}(2) \cdots \mathrm{O}(3)$ & $2 \cdot 977(3)$ & $2 \cdot 00(5)$ & $177(2)$ & $1-x,-\frac{1}{2}+y,-\frac{1}{2}-z$ \\
$\mathrm{C}(19)-\mathrm{H}(19) \cdots \mathrm{O}\left(1^{\prime}\right)$ & $3 \cdot 227(4)$ & $2 \cdot 83(6)$ & $101(3)$ & $x, 1+y, z$ \\
$\mathrm{C}(20)-\mathrm{H}(20) \cdots \mathrm{O}\left(1^{\prime \prime}\right)$ & $3 \cdot 281(4)$ & $2 \cdot 53(6)$ & $137(3)$ & $-1+x, 1+y, z$ \\
$\mathrm{C}(23)-\mathrm{H}(232) \cdots \mathrm{O}\left(2^{\prime}\right)$ & $3 \cdot 193(3)$ & $2 \cdot 72(5)$ & $111(2)$ & $-1+x, y, z$
\end{tabular}

tance $C(1)-C(2), 1 \cdot 317$ (4) $\AA$, is shorter compared to the other three $\mathrm{C}=\mathrm{C}$ distances $[\mathrm{C}(14)-\mathrm{C}(15)$, $\mathrm{C}(18)-\mathrm{C}(19)$ and $\mathrm{C}(20)-\mathrm{C}(21)$ ] in the molecule, with an average value of 1.344 (4) $\AA$.

Fig. 2 shows the molecular stacking in the unit cell. Along with $\mathrm{O}-\mathrm{H} \cdots \mathrm{O}$ interactions, intermolecular C- $\mathrm{H} \cdots \mathrm{O}$ interactions (Taylor \& Kennard, 1982; Das, Sinha, Narkhede \& Manisekharanan, 1990) are observed (Table 2).

\section{References}

Das, K., Sinha, U. C., Narkhede, D. D. \& Manisekharanan, T. (1990). Acta Cryst. C46, 1888-1890.

Gaikwad, B. R., Mayelvaganan, T., Vyas, B. A. \& Bhat, S. V. (1990). Phytochemistry, 29, 3963-3965. 
Kraus, W., Cramer, R. \& Sawitzki, G. (1981). Phytochemistry, 20, 117-120.

Main, P., Germain, G. \& Woolfson, M. M. (1984). MULTAN84. A System of Computer Programs for the Automatic Solution of Crystal Structures from $X$-ray Diffraction Data. Univs. of York, England, and Louvain, Belgium.

Motherwell, W. D. S. \& ClegG, W. (1978). PLUTO. Program for plotting molecular and crystal structures. Univ. of Cambridge, England.

Pillai, N. R. \& Santhakumari, G. (1981). Planta Med. 43(1), 59-63.

Pillai, N. R. \& Santhakumari, G. (1984). Planta Med. 50(2), 143-146.
SChmutterer, H. \& Ascher, K. R. S. (1983). In Proceedings of the 2nd International Neem Conference, Ravischhalzausen, Germany. Eschborn: Ot. Gesellschaft für Technologie Zusammenarbeit.

Schmutterer, H., Ascher, K. R. S. \& Rembold, H. (1980). In Proceedings of the 1st International Neem Conference, Rottach Egern, Germany. Eschborn: German Agency for Technical Cooperation.

SHELDRICK, G. M. (1976). SHELX76. Program for crystal structure determination. Univ. of Cambridge, England.

Siddiqui, S., Siddiqui, B. S., Faizi, S. \& MahmoOd, T. (1988). $J$. Nat. Prod. 51, 30-43.

TaYlor, R. \& KenNard, O. (1982). J. Am. Chem. Soc. 104, 5063-5070.

Acta Cryst. (1991). C47, 1429-1432

\title{
Structure of 2-Aminodinaphtho|2,1-d:1', $2^{\prime}-f \mid[1,3,2 \mid$ dioxaphosphepine-2-thione- Di-n-butylamine Adduct
}

\author{
By S. Selladurai and K. Subramanian \\ Department of Physics, Anna University, Madras-25, India \\ AND C. NAGARAJU \\ Department of Chemical Engineering, SV University, Tirupathi, India
}

(Received 10 August 1990; accepted 15 October 1990)

\begin{abstract}
C}_{29} \mathrm{H}_{33} \mathrm{~N}_{2} \mathrm{O}_{2} \mathrm{PS}, M_{r}=492 \cdot 6$, triclinic, $P \overline{1}, a$ $=8.8737(6), b=12.6312(8), c=13.8424(8) \AA, \alpha=$ $111.797(6), \quad \beta=104.103(5), \quad \gamma=97.005(5)^{\circ}, \quad V=$ $1357.9 \AA^{3}, \quad Z=2, \quad D_{x}=1.20 \mathrm{~g} \mathrm{~cm}^{-3}, \quad \lambda(\mathrm{Cu} K \alpha)=$ $1.5418 \AA, \mu=17.9 \mathrm{~cm}^{-1}, F(000)=524, T=295 \mathrm{~K}$, $R=0.065$ for 4778 observed reflections. The sevenmembered phosphepine ring is in a boat conformation. The bond length, $\mathrm{P}=\mathrm{S}$, is 1.924 (2) $\AA$. The naphthalene rings are planar. The crystal structure is stabilized by an $\mathrm{N}-\mathrm{H} \cdots \mathrm{N}$ intermolecular hydrogen bond $\mathrm{N}(24) \cdots \mathrm{N}(25)$ with $\mathrm{N} \cdots \mathrm{N}$ distance and $\mathrm{N}-\mathrm{H} \cdots \mathrm{N}$ angle $2.72(2) \AA$ and $166.5(2)^{\circ}$, respectively.
\end{abstract}

Introduction. The chemistry of organophosphorus compounds has received tremendous attention during the past two decades because of its vital role in both life-sustaining and life-destroying activities (Corbridge, 1975; Garcia-Blanco \& Perales, 1972). The title compound belongs to the category of lifedestroying substances viz. insecticides, bactericides, flame retardants, etc. (Ismail, 1975). The organophosphates form a wide spectrum of insecticides and pesticides effective against aphids, mites, lepidoptera, beetles, leaf-hoppers and thrips on fruits, vegetables and crops, and for this reason its X-ray structure is of great interest to our continuing investigations.

0108-2701/91/071429-04\$03.00
Experimental. Transparent needle-shaped crystals were obtained by slow evaporation from methanol. Crystal, $0.53 \times 0.23 \times 0.08 \mathrm{~mm}$, used for all measurements. Accurate cell parameters obtained from leastsquares refinement using $2 \theta$ values of 25 mediumangle reflections $\left(35<\theta<45^{\circ}\right)$. Intensity data collected using $\omega / 2 \theta$ scan technique on Enraf-Nonius CAD-4 diffractometer with graphite-monochromatized $\mathrm{Cu} K \alpha$ radiation. Intensities of two standard reflections monitored periodically during data collection, no significant variation. Intensities of reflections $2<\theta<75^{\circ}$ measured $(h:-10-10, k:-14-14, l$ : $0-14) .5385$ independent reflections measured, 4778 reflections had $I>3 \sigma(I)$. The intensity data were corrected for Lorentz and polarization effects, no absorption correction was applied. The structure was solved by direct methods using the program SHELXS86 (Sheldrick, 1986). All the $\mathrm{H}$ atoms except those attached to $\mathrm{N}$ atoms and methyl group atoms located on a difference density map. $\mathrm{H}$ atoms attached to $\mathrm{N}$ atoms and methyl groups fixed geometrically and checked in the difference map. Positional parameters of all atoms and anisotropic thermal parameters of non-H atoms refined (on $F$ ) by full-matrix least-squares methods. Final $R=$ 0.065 and $w R=0.075$ for 4778 observed reflections, $w=K /\left(\sigma^{2}\left|F_{o}\right|+m\left|F_{o}\right|^{2}\right) \quad(K=2 \cdot 3900, \quad m=0.000469)$.

(C) 1991 International Union of Crystallography 